\title{
Evaluation of the phosphate solubilization potential of Trichoderma strains (Trichoplus JCO) and effects on rice biomass
}

\author{
L.F. Borges Chagas ${ }^{1}$, A.F. Chagas Junior ${ }^{1}$, M. Rodrigues de Carvalho ${ }^{2}$, L. de Oliveira \\ Miller $^{2}$, B. S. Orozco Colonia ${ }^{1 *}$ \\ ${ }^{1}$ Department of Agricultural Sciences and Technology, Federal University of Tocantins (UFT), Rua Badejós, \\ CEP 7740-2970 Gurupi, Tocantins, Brazil. ${ }^{*}$ Corresponding author: bsorozco@uft.edu.br \\ ${ }^{2}$ Department of Phytopathology, JCO Fertilizers and Bioproducts Company, CEP 4780-1651 Vila Nova, \\ Barreiras, Bahia, Brazil.
}

\begin{abstract}
This study aims to evaluate the phosphate solubilization potential of the Trichoderma spp. isolates found in the commercial product Trichoplus JCO. The strains were isolated, molecularly identified and grown in vitro. The soluble phosphate concentration was quantified at 3, 6, 9 and 12 days after transplanting. Rice was inoculated with the Trichoderma strains in greenhouse conditions with 10 to $60 \times 10^{8}$ conidia per gram of rice and then planted. At 30 and 45 days after planting (DAP), plant growth characteristics were determined. The phosphate concentrations of most of the Trichoderma strains showed a general trend of increasing from days 3 to 9. At 30 DAP, Tr. Harz and Tr. TSM had a higher significant difference. At 45 DAP, the rice inoculated with Tr. Harz, Tr. Euc and Tr. TSM had the greatest increase in the total dry matter compared with the control. The rice inoculated with Tr. Euc and Tr. TSM had the best relative efficiencies, and the rice inoculated with Tr. Din and Tr. TSM demonstrated the highest P-UEF. Finally, the rice inoculated with Tr. Harz (T. asperelloides), Tr. Euc (T. harzianum) and Tr. TSM (T. harzianum) had the highest efficiency in phosphate solubilization with increases in rice biomass.
\end{abstract}

Keywords: Phosphate solubilization, rice, biomass, Trichoderma, greenhouse

\section{Introduction}

The expansion in agricultural frontiers in the Brazilian savannah, now a large producer of soybeans, rice and beans, is essential to the agricultural development of the country. However, the agricultural advances in this region have been hindered by the soil characteristics generated by the weather and the resulting naturally low levels of fertility, especially phosphorus (Novais and Smyth, 1999). 
The high productivity of crops such as rice is generally associated with the utilization, among other factors, of a high dosage of fertilizers. However, fertilizers represent a significant portion of the cost of crop production, are obtained from non-renewable resources and can potentially increase environmental pollution.

Phosphorus (P) is second followed by Nitrogen (N) as the most limiting macronutrient to plant growth (Balemi and Negisho, 2012), representing approximately $0.2 \%$ of the dry matter (Schachtman et al., 1998). The soluble $\mathrm{P}$ soil concentration varies from 0.05 to $10 \mathrm{ppm}$, and in soil, more than $80 \%$ of the $\mathrm{P}$ becomes fixed and unavailable for absorption by plants due to adsorption, precipitation or conversion to organic forms (Holford, 1997). The fixed form of $\mathrm{P}$ in alkaline soils is calcium triphosphate $\left(\mathrm{Ca}_{3}\left(\mathrm{PO}_{4}\right)_{2}\right)$, whereas in acidic soils, it is mainly found as $\mathrm{FePO}_{4}$ and $\mathrm{AlPO}_{4}$ (Subba Rao, 1999).

Many researchers have noted that a high proportion of phosphate-solubilizing microorganisms (PSM), especially bacteria, fungi and actinomycetes, reside in the rhizosphere of plants and play an important role in phosphate solubilization, converting phosphate into soluble compounds for plants (Sujatha et al., 2004; Gravel et al., 2007). Fungi have the largest capability for solubilizing rock phosphate (Barroso and Nahas, 2008; Minaxi et al., 2013).

Fungi of the Trichoderma genus are among the microorganisms most commonly studied as biological control agents and plant growth promoters (Gravel et al.; 2007; Santos et al., 2010; Machado et al., 2011; Oliveira et al., 2012). The radicular colonization of the Trichoderma genus frequently increases root growth, plant development, absorption of nutrients, resistance to abiotic stress and consequently productivity (Harman et al., 2004). A number of studies have demonstrated the ability of species of Trichoderma to promote the growth of several different types of plants and protect them against plant pathogens (Kapri and Tewari, 2010; Santos et al., 2010; Machado et al., 2011; Hannan et al., 2013).

Considering the low level of soil fertility in the Brazilian savannah, this study was designed to evaluate the "in vitro" potential for phosphate solubilization by Trichoderma spp. isolates contained in the commercial product Trichoplus JCO (JCO Fertilizers and Bioproducts), JCO fertilizers, located in Barreiras, Bahia, Brazil. The isolates were inoculated in soil fertilized with natural phosphate and evaluated for an effect on rice biomass under greenhouse conditions

\section{Materials and Methods}

\subsection{In vitro potential solubilization of phosphate}

The experiments were conducted from December 2013 to April 2014 in the Microbiology Laboratory of the Federal University of Tocantins, Gurupi Campus. The strains used in the study were obtained from JCO Fertilizers and Bioproducts and are a part of a mix of fungi that is used to make the commercial product trichoplus (Table 1). The strains were identified by sequencing the ITS region at the Institute Biological, São Paulo.

During the in vitro phosphate solubilization tests, the Trichoderma spp. strains were cultivated initially on potato dextrose agar (PDA) culture medium at $28{ }^{\circ} \mathrm{C}$ for seven days. From the resulting colonies, discs approximately $8.0 \mathrm{~mm}$ in diameter containing mycelium and conidia were placed in a $250-\mathrm{mL}$ Erlenmeyer flask containing $100 \mathrm{~mL}$ of modified NBRIP (g.L $\mathrm{L}^{-1}$ ): glucose, $10 ; \mathrm{MgCl}_{2} .6 \mathrm{H}_{2} \mathrm{O}, 5.0$; $\mathrm{MgSO}_{4} .7 \mathrm{H}_{2} \mathrm{O}, 0.25 ; \mathrm{KCl}, 0.2 ;\left(\mathrm{NH}_{4}\right)_{2} \mathrm{SO}_{4}, 0.1$ and tri-calcium phosphate $\left(\mathrm{Ca}_{3} \mathrm{HPO}_{4}\right), 10.0$. Then, the cultures were tested for their potential to solubilize phosphate in vitro (Nautyal, 1999). 
The estimated quantity of solubilized phosphate was determined in triplicate using a completely randomized trial design. The flasks were incubated at $28 \pm 1{ }^{\circ} \mathrm{C}$ shaking at $150 \mathrm{rpm}$ for eight days. The evaluations were conducted three, six, nine and twelve days after cultivation. The colorimetric method of Murphy and Riley (1962) was used to determine the concentration of soluble $\mathrm{P}$, subtracting the amount of soluble $\mathrm{P}$ in the control (culture medium with phosphate and no fungi) from that in the treatment cultures. For the determination of the concentration of soluble $\mathrm{P}, 0.5$ $\mathrm{mL}$ of the filtered sample and $5 \mathrm{~mL}$ of distilled water were combined. After 20 minutes, the reaction of soluble $\mathrm{P}$ was quantified in the spectrophotometer at a wavelength of $725 \mathrm{~nm}$. The standard curve to quantify the $\mathrm{P}$ concentration was made based on the tricalcium phosphate solution and the calculated concentrations $\mu \mathrm{g} \cdot \mathrm{mL}^{-1}$.

Table 1. Trichoderma strains in the commercial product Trichoplus JCO.

\begin{tabular}{|c|c|c|c|}
\hline Strain & Species ID & $\begin{array}{l}\text { GenBank } \\
\text { Access }\end{array}$ & $\begin{array}{l}\text { Similarity } \\
\text { Index }(\%)\end{array}$ \\
\hline UFT-Tr. Harz & T. asperelloides GJS04-217 & DQ381958 & 100 \\
\hline UFT-Tr. Din & T. longibrachiatum DAOM 167674 & EU280099 & 100 \\
\hline UFT-Tr. Euc & T. harzianum CIB T44 & EU280077 & 100 \\
\hline UFT-Tr. TSM & T. harzianum CIB T44 & EU280077 & 100 \\
\hline UFT-Tr. Grupo OK & T. asperelloides GJS 04-217 & DQ381958 & 100 \\
\hline
\end{tabular}

\subsection{Inoculation of Trichoderma in rice under greenhouse conditions}

The strains were grown separately in petri plates containing PDA culture medium and incubated at $25^{\circ} \mathrm{C} \pm 2{ }^{\circ} \mathrm{C}$ with a 12 -hour photoperiod for 7 days, a period determined for the growth of Thrichoderma according to Watts et al. (1988). Polypropylene bags containing $300 \mathrm{~g}$ of rice and $300 \mathrm{~mL}$ of distilled water were autoclaved at $121^{\circ} \mathrm{C}$ for 1 hour and after cooling down, were inoculated with 6 discs, 5-mm in diameter, of one of the Trichoderma strains. After inoculation, the bags were placed on germination chamber BOD (Biochemical Oxygen Demand) at $25^{\circ} \mathrm{C}$ with a 12 - hour photoperiod for 7 days. The bags were manually mixed at 2-day intervals to facilitate the exchange of gases, break down mycelia aggregates, and increase sporulation. Subsequently, after 7 days of incubation, $30 \mathrm{~g}$ from each bag was saved to inoculate the soil. The concentration of Trichoderma spp. was determined by quantifying the number of conidia. One gram of rice was washed in $10 \mathrm{~mL}$ of distilled water and agitated for 1 minute. Then the number of conidia was counted in a Neubauer chamber using an optical microscope. For the experiment, $10 \times 10^{8}$ conidia per gram of colonized rice were used. Rice without Trichoderma served as the control. 
The strains of Trichoderma were mixed with screened soil and placed in a 1.7-L vase for 7 days to allow the colonization of the substrate before rice planting. Before planting, a composite soil sample was collected for physical and chemical analysis, revealing the following results: $1.7 \mathrm{cmol}_{\mathrm{c}} \mathrm{dm}^{-3}$ of $\mathrm{Ca} ; 0.6 \mathrm{cmol}_{\mathrm{c}} \mathrm{dm}^{-3}$ of $\mathrm{Mg} ; 17.4 \mathrm{cmol}_{\mathrm{c}} \mathrm{dm}^{-3}$ of $\mathrm{K} ; 1.7$ $\mathrm{mg} \mathrm{dm} \mathrm{dm}^{-3}$ of $\mathrm{P} ; 0.07 \mathrm{cmol}_{\mathrm{c}} \mathrm{dm}^{-3}$ of $\mathrm{Al} ; 7.4 \mathrm{cmol}_{\mathrm{c}} \mathrm{dm}^{-3}$ of CTC; $2.3 \mathrm{cmol}_{\mathrm{c}} \mathrm{dm}^{-3}$ of SB; $39 \%$ of V; $\mathrm{pH} 5.4$ in water; $1.0 \%$ of organic matter; texture of $72.3,8.2$ and $19.5 \%$ of sand, silt and clay, respectively. The chemical attributes in the soil depth of 0-20 cm were determined. The $\mathrm{pH}$ was measured potentiometrically (soil:water, 1:2.5 v/v), P and $\mathrm{K}$ were extracted using Mehich 1; $\mathrm{Al}^{3+}, \mathrm{Ca}^{2+}$ and $\mathrm{Mg}^{2+}$ were extracted with $\mathrm{KCl}\left(1 \mathrm{~mol} \mathrm{~L}^{-1}\right) ; \mathrm{H}+\mathrm{Al}$ was extracted with SMP; TEB $=$ Total Exchangeable; $(\mathrm{CEC})=$ Cation Exchange Capacity at $\mathrm{pH}$ 7.0; $\mathrm{V}=$ Base Saturation Index; and $\mathrm{SOM}=$ Soil Organic Matter (oxidation: $\mathrm{Na}_{2} \mathrm{Cr}_{2} \mathrm{O}_{7} 4 \mathrm{~N}$ $\left.+\mathrm{H}_{2} \mathrm{SO}_{4} 10 \mathrm{~N}\right)$.

The soil, which was deficient in $\mathrm{P}$, was supplemented with insoluble natural phosphate at a rate of 100 $\mathrm{mg} \cdot \mathrm{kg}^{-1}$ of soil. The phosphate concentration was $32 \%$ total $\mathrm{P}_{2} \mathrm{O}_{5}$ and $2 \% \mathrm{P}_{2} \mathrm{O}_{5}$ soluble in citric acid.

The rice seeds were planted, adding six seeds per vase, and the excess plants were removed 5 days after germination, leaving only the two best plants per vase. The plants were harvested 30 to 45 days after planting (DAP). Later, the height of plants (HT), root length (RT), leaf dry matter (LDM), root dry matter (RDM) and total dry matter (TDM) were determined. At 45
DAP, the phosphorus leaf content was determined (Embrapa, 1997). Using the biomass information, it was possible to define the relative efficiency (RE) for each treatment using the following formula: RE $=(\mathrm{LDM}$ rice inoculated with Trichoderma $/ \mathrm{LDM}$ control) $\mathrm{x}$ 100. The P content of the leaves was used to calculate the P utilization efficiency (P-UEF) in the rice plants using the following formula (Rodrigues et al., 2003): P-UEF $=\left[(\text { dry matter })^{2} /(\right.$ nutrient level $\left.)\right]$. The data were evaluated using analysis of variance with the F-test, and the averages grouping was promoted by the Scott-Knott method at 5\% using the Assistat statistical program (Version 7.6)

\section{Results}

\subsection{In vitro Phosphate solubilization potential}

All of the Trichoderma species showed good mycelial growth in modified NBRIP medium. A general trend was observed of the concentration of solubilized phosphate gradually increasing from days 3 to 9 and then diminishing around day 12 ; the pattern observed with T. asperelloides GJS04-217 (UFT-Tr. Harz) differed from this trend (Table 2). The phosphate concentrations in the filtration from the various strains varied from 2.13 to $12.05 \mu \mathrm{g} \cdot \mathrm{mL}^{-1}$ in the first evaluation three days after Trichoderma was added to the solution, from 9.62 to $11.18 \mu \mathrm{g} \cdot \mathrm{mL}^{-1}$ on day six, from 11.41 to $24.88 \mu \mathrm{g} \cdot \mathrm{mL}^{-1}$ on day nine and 16.01 to $20.73 \mu \mathrm{g} \cdot \mathrm{mL}^{-1}$ in the last evaluation, on day 12 . 
Table 2. Solubilization of tri-calcium phosphate $\left(10\right.$ g. $\left.\mathrm{L}^{-1}\right)$ in modified NBRIP medium by Trichoderma strains (Trichoplus JCO) at varying intervals) (a).

\begin{tabular}{lcccc}
\hline \multirow{2}{*}{ Strain } & \multicolumn{4}{c}{ Concentration of solubilized phosphate $\left(\mu \mathrm{g} \cdot \mathrm{mL}^{-1}\right)$} \\
\cline { 2 - 5 } & Day 3 & Day 6 & Day 9 & Day 12 \\
\hline UFT-Tr. Harz & $12.05 \mathrm{a}$ & $9.88 \mathrm{a}$ & $11.41 \mathrm{c}$ & $20.73 \mathrm{a}$ \\
UFT-Tr. Din & $6.17 \mathrm{~b}$ & $9.62 \mathrm{a}$ & $18.39 \mathrm{~b}$ & $16.07 \mathrm{~b}$ \\
UFT-Tr. Euc & $2.31 \mathrm{c}$ & $11.18 \mathrm{a}$ & $22.08 \mathrm{a}$ & $21.43 \mathrm{a}$ \\
UFT-Tr. TSM & $2.13 \mathrm{c}$ & $11.08 \mathrm{a}$ & $24.88 \mathrm{a}$ & $20.34 \mathrm{a}$ \\
UFT-Tr. Gok & $2.71 \mathrm{c}$ & $10.98 \mathrm{a}$ & $19.56 \mathrm{~b}$ & $16.01 \mathrm{~b}$ \\
Control & $0.24 \mathrm{~d}$ & $0.47 \mathrm{~b}$ & $0.46 \mathrm{~d}$ & $0.44 \mathrm{c}$ \\
\hline CV (\%) (b) & 22.5 & 20.8 & 18.7 & 12.9
\end{tabular}

a) Averages followed by the same letter in a column are not significantly different from each other as determined by the ScottKnott test at $5 \%$.

b) Coefficient of Variation.

The solubilization of phosphates by Trichoderma cultures starting on the third day indicates the high potential of Trichoderma to solubilize inorganic phosphate, which would normally be used by the fungus in cellular processes. All of the Trichoderma strains showed potential in solubilizing phosphate; nonetheless UFT-Tr. Harz (T. asperelloides), UFT-Tr. Euc (T. harzianum) and UFT-Tr. TSM (T. harzianum) were most effective (Table 2).

Moreover, a gradual strain-dependent decrease in the $\mathrm{pH}$ was observed for all of the strains; the $\mathrm{pH}$ values later became constant (Figure 1).

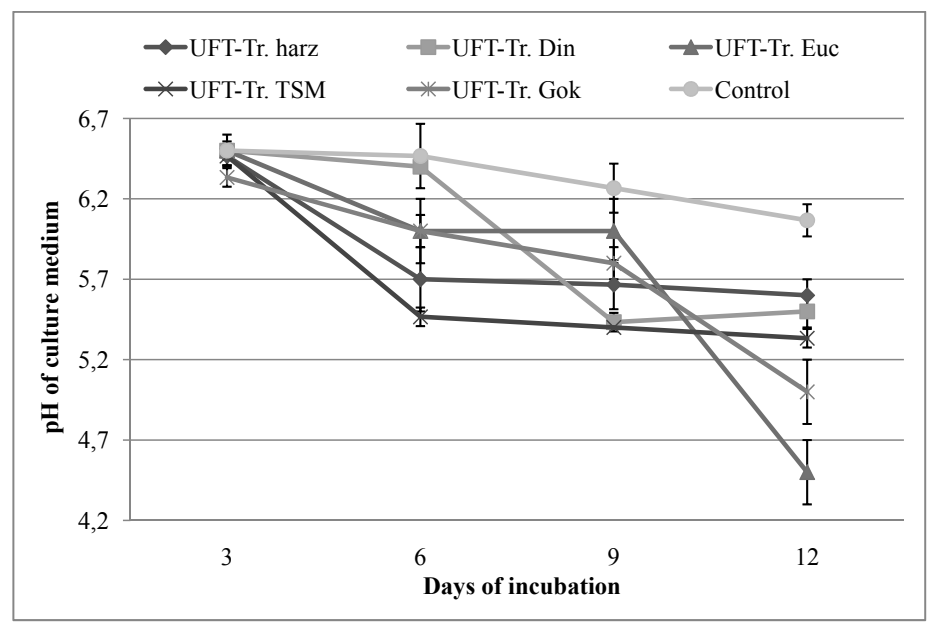

Figure 1. $\mathrm{pH}$ of the liquid culture medium (modified NBRIP) after incubation with Trichoderma strains (Trichoplus JCO) that solubilize phosphate in the presence of tri-calcium phosphate. 


\subsection{Trichoderma inoculation of rice under greenhouse conditions}

The influence of Trichoderma inoculation of rice was determined 30 to 45 DAP by measuring different growth parameters, including height, root length and dry matter. Plant growth was significantly increased in the presence of natural phosphate stimulated by Trichoderma inoculation compared with the plant growth of the control with no Trichoderma, as evidenced by the significant increase in all the growth parameters shown in Table $3(p<0.01)$. At 30 DAP, the growth characteristics of the plants inoculated with Trichoderma strains UFT-Tr. Harz and UFT-Tr. TSM were significantly greater than those of the plants inoculated with the other isolates $(p<0.01)$. At 45 DAP, most of the growth characteristics of the plants inoculated with strains UFT-Tr. Harz, UFT-Tr. Euc and UFT-Tr. TSM were significantly greater than those of the plants inoculated with the other strains $(p<0.01)$.

Table 3. Height, root length (RL), leaf dry matter (LDM), root dry matter (RDM) and total dry matter (TDM) of rice plants inoculated with Trichoderma (Trichoplus JCO) (a).

\begin{tabular}{|c|c|c|c|c|c|c|}
\hline Strains & $\begin{array}{l}\text { Height } \\
(\mathrm{cm})\end{array}$ & $\begin{array}{c}\mathrm{RL} \\
(\mathrm{cm})\end{array}$ & $\begin{array}{l}\text { LDM } \\
(\mathrm{g})\end{array}$ & $\begin{array}{c}\text { RDM } \\
\text { (g) }\end{array}$ & $\begin{array}{c}\text { TDM } \\
(\mathrm{g})\end{array}$ & $\begin{array}{l}\text { TDM } \\
\% \text { (b) }\end{array}$ \\
\hline & \multicolumn{6}{|c|}{30 DAP } \\
\hline UFT-Tr. Harz & $27.3 \mathrm{a}$ & $29.0 \mathrm{a}$ & $0.18 \mathrm{a}$ & $0.28 \mathrm{a}$ & $0.46 \mathrm{a}$ & 188 \\
\hline UFT-Tr. Din & $20.7 \mathrm{~b}$ & $26.7 \mathrm{a}$ & $0.12 \mathrm{~b}$ & $0.15 \mathrm{~b}$ & $0.27 \mathrm{~b}$ & 69 \\
\hline UFT-Tr. Euc & $24.0 \mathrm{~b}$ & $26.7 \mathrm{a}$ & $0.13 \mathrm{~b}$ & $0.16 \mathrm{~b}$ & $0.29 \mathrm{~b}$ & 81 \\
\hline UFT-Tr. TSM & $31.3 \mathrm{a}$ & $27.3 \mathrm{a}$ & $0.21 \mathrm{a}$ & $0.34 \mathrm{a}$ & $0.55 \mathrm{a}$ & 244 \\
\hline UFT-Tr. Gok & $21.0 \mathrm{~b}$ & $25.3 \mathrm{a}$ & $0.09 \mathrm{c}$ & $0.16 \mathrm{~b}$ & $0.25 \mathrm{~b}$ & 56 \\
\hline Control & $18.0 \mathrm{c}$ & $21.0 \mathrm{~b}$ & $0.07 \mathrm{c}$ & $0.09 \mathrm{c}$ & $0.16 \mathrm{c}$ & -- \\
\hline \multirow[t]{2}{*}{ CV (\%) (c) } & 11.5 & 11.4 & 9.1 & 19.1 & 13.8 & \\
\hline & \multicolumn{6}{|c|}{45 DAP } \\
\hline UFT-Tr. Harz & $32.0 \mathrm{~b}$ & $22.0 \mathrm{a}$ & $0.42 \mathrm{~b}$ & $1.25 \mathrm{a}$ & $1.67 \mathrm{a}$ & 139 \\
\hline UFT-Tr. Din & $25.7 \mathrm{~b}$ & $22.1 \mathrm{a}$ & $0.41 \mathrm{~b}$ & $0.48 \mathrm{c}$ & $0.89 \mathrm{~b}$ & 27 \\
\hline UFT-Tr. Euc & $37.3 \mathrm{a}$ & $22.4 \mathrm{a}$ & $0.53 \mathrm{a}$ & $1.06 \mathrm{a}$ & $1.59 \mathrm{a}$ & 127 \\
\hline UFT-Tr. TSM & $39.7 \mathrm{a}$ & $18.0 \mathrm{~b}$ & $0.56 \mathrm{a}$ & $0.78 \mathrm{~b}$ & $1.34 \mathrm{a}$ & 91 \\
\hline UFT-Tr. Gok & $33.0 \mathrm{~b}$ & $22.0 \mathrm{a}$ & $0.43 \mathrm{~b}$ & $0.42 \mathrm{c}$ & $0.85 \mathrm{~b}$ & 21 \\
\hline Control & $33.0 \mathrm{~b}$ & $19.3 \mathrm{~b}$ & $0.35 \mathrm{~b}$ & $0.35 \mathrm{c}$ & $0.70 \mathrm{~b}$ & -- \\
\hline CV (\%) (c) & 11.3 & 5.5 & 9.4 & 11.9 & 12.9 & \\
\hline
\end{tabular}

a) Averages followed by the same letter in a column are not significantly different as determined by the Scott-Knott test at $5 \%$.

b) The increase in the TDM of the rice inoculated with Trichoderma compared with that of the control expressed as a percentage of the control.

c) Coefficient of Variation. 
The relative efficiency (RE), which relates to the leaf biomass, was significantly greater for the rice inoculated with Trichoderma (Trichoplus JCO) than that of the control $(p<0.01)$. In particular, the rice inoculated with the strains UFT-Tr. Euc and UFT-Tr. TSM showed the largest values for RE (Figure 2).

The leaf $\mathrm{P}$ content and the $\mathrm{P}$ utilization efficiency (P-UEF) were greater in the rice inoculated with Trichoderma than in the control $(p<0.01)$
Moreover, the rice inoculated with strains UFTTr. Din and UFT-Tr. TSM were superior to the other strains with respect to $\mathrm{P}$ content and $\mathrm{P}-\mathrm{UEF}$ $(p<0.01)$ (Table 4). The increases in the amount of $\mathrm{P}$ and the P-UEF after inoculation with the Trichoderma isolates compared with that of the controls expressed as a percentage of the controls ranged from 10 to $61 \%$ and 12 to $62 \%$, respectively.

Table 4. Phosphorus content (P) and utilization efficiency of phosphorus (P-UEF) in rice inoculated with Trichoderma (a).

\begin{tabular}{lcccc}
\hline Treatment & $\begin{array}{c}\mathrm{P} \\
\left(\mathrm{g} \mathrm{kg}^{-1}\right)\end{array}$ & $\begin{array}{c}\mathrm{P} \\
\%(\mathrm{~b})\end{array}$ & $\begin{array}{c}\text { P-UEF } \\
\text { UFT-Tr. Harz }\end{array}$ & $\begin{array}{c}\text { P-UEF } \\
\%(\mathrm{c})\end{array}$ \\
UFT-Tr. Din & $2.28 \mathrm{~b}$ & 11 & $0.047 \mathrm{~b}$ & 12 \\
UFT-Tr. Euc & $3.06 \mathrm{a}$ & 49 & $0.063 \mathrm{a}$ & 50 \\
UFT-Tr. TSM & $2.32 \mathrm{~b}$ & 13 & $0.048 \mathrm{~b}$ & 14 \\
UFT-Tr. Gok & $3.32 \mathrm{a}$ & 61 & $0.068 \mathrm{a}$ & 62 \\
Control & $2.27 \mathrm{~b}$ & 10 & $0.047 \mathrm{~b}$ & 12 \\
\hline \multicolumn{1}{c}{ CV (\%)(d) } & $2.06 \mathrm{c}$ & - & $0.042 \mathrm{c}$ & -- \\
\hline
\end{tabular}

a) Averages followed by the same letter in a column are not significantly different as determined by the Scott-Knott test at $5 \%$.

b) The increase in the $\mathrm{P}$ content in the shoots of the rice inoculated with Trichoderma compared with that of the control expressed as a percentage of the $\mathrm{P}$ content of the control.

c) The increase in the P-UEF of the rice inoculated with Trichoderma compared with that of the control expressed as a percentage of the P-UEF of the control.

d) Coefficient of Variation.

\section{Discussion}

The gradual decrease in the $\mathrm{pH}$ values (Figure 1) is consistent with the previous findings of Ilmer and Schinner (1992), who also reported a diminished $\mathrm{pH}$ for 4 days, followed by a gradual increase during phosphate solubilization of Penicilliume Pseudomonas in liquid fermentation. It has been suggested that the microorganisms that tend to decrease the $\mathrm{pH}$ of a culture medium are efficient in solubilizing phosphate (Schoebitz et al., 2013). However, in cultures in which the $\mathrm{pH}$ decreases during the first 48 hours of growth and subsequently stabilizes, the concentration of soluble phosphate continues to increase after 48 hours. This clearly suggests that the $\mathrm{pH}$ drop is not the only factor necessary for $\mathrm{P}$ solubilization. A reduction 
in the $\mathrm{pH}$ of a medium containing several species of fungi was also observed by Alam et al. (2002), Souchie et al. (2005) and Vassilev et al. (2006). An increase in the initial concentration of phosphate followed by a gradual decrease as seen in this study has also been documented in other studies (Nautiyal, 1999). The decrease in phosphate concentration observed for most of the Trichoderma strains after 12 days correlates with the use of $\mathrm{P}$ to facilitate the mycelial growth of Trichoderma; the $\mathrm{P}$ would later be available for the plant roots, which are in close proximity with the mycelium. In the natural habitat, plant pathogenic fungus, such as Pythium and Rhizoctonia, are incapable of solubilizing phosphate and can be easily suppressed by the high efficiency of Trichoderma harzianum though $\mathrm{P}$ absorption (Altmare et al., 1999). In addition to the solubilization of $\mathrm{P}$, the simultaneous synthesis and liberation of metabolites such as siderophores, phytohormones and lytic enzymes by phosphatesolubilizing microorganisms can be useful (Vassilev et al., 2006). The capacity for phosphate solubilization of fungi in different solid and liquid growth medium has also been reported by other authors (Silva Filho et al., 2002; Alam et al., 2002; Souchie et al., 2005).

The inoculation of Trichoderma significantly increased the rock phosphate solubilization and consequently the absorption of $\mathrm{P}$ by the rice plants. The capacity of phosphate solubilization by soil microorganisms has been known to influence rice production (Sutaliya and Singh, 2005; AsumingBrempong, 2013).

According to Brotman et al. (2010), Trichoderma spp. species can increase plant growth by up to
$300 \%$. The results of the present work corroborate those of Silva et al. (2011), who evaluated the effect of Trichoderma on the growth of pickle plants and observed a significant increase in pickle plant growth compared with the no Trichoderma control.

In our study, there was an increase varying from 56 to $188 \%$ in the TDM at 30 DAP and from 21 to $139 \%$ at 45 DAP in relation to the control (Table $3)$. Although, there were significant differences in the biomass parameters among the rice plants inoculated with the different Trichoderma strains, all of the strains were directly involved in the growth promotion of rice, most likely by the dissolution of natural phosphate.

Reyes et al. (2002) reported that strains of Penicillium regulosum that solubilized phosphate were capable of stimulating the growth of corn plants, with an increase of 3.6 to $28.6 \%$ in the dry matter produced under greenhouse conditions. Rudresh et al. (2005) found that inoculation with Trichoderma resulted in an increase in the growth and production parameters of Cichorium intybus L. cultivated in P-deficient soil and fertilized with insoluble rock phosphate under greenhouse conditions.

These results are similar to those reported by Kapri and Tewari (2010) for Cichorium intybus L. grown in a greenhouse in soil supplemented with tri-calcium phosphate (insoluble). This study demonstrated that when Cichorium intybus $\mathrm{L}$. was inoculated with Trichoderma, the capacity to solubilize phosphate in vitro was increased, providing evidence of the parameter biomass of Cichorium intybus $\mathrm{L}$. 


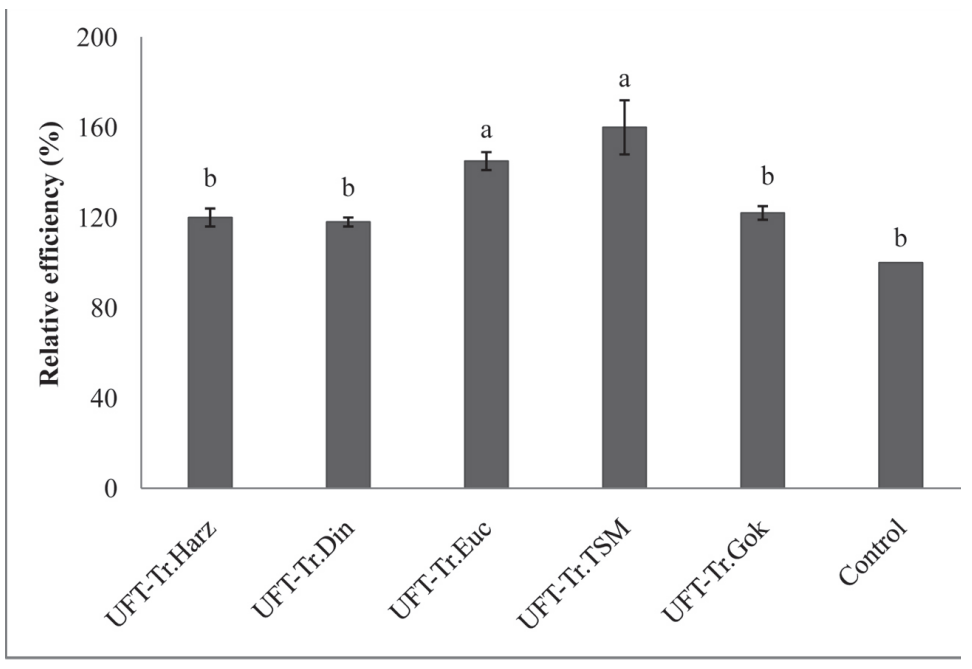

Figure 2. Relative efficiency of rice inoculated with Trichoderma (Trichoplus JCO) compared to the control without inoculation.

\section{Conclusion}

All of the strains of Trichoderma found in Trichoplus JCO were capable of solubilizing phosphate in culture medium. The most efficient strains were UFT-Tr., UFTTr. Euc and UFT-Tr. TSM. Furthermore, these strains of Trichoderma significantly increased the biomass parameters and P nutrition of rice grown under greenhouse conditions, suggesting its potential applicability in the improvement of the crop.

\section{Acknowledgements}

The authors gratefully acknowledge the $\mathrm{CNPq} /$ Bionorte and the partnership with JCO Fertilizers and Bioproducts.

\section{References}

Alam, S., Khalil, S., Ayub, N., Rashid, M. 2002. In vitro solubilization of inorganic phosphate by phosphate solubilizing microorganisms (PSM) from Maize rhizosphere. Int. J. Agr. Biol. 4(4), 454-458.

Asuming-Brempong, S. 2013. Phosphate solubilizing microorganisms and their ability to influence yield of rice. Agr. Sci. Res. J. 3(12), 379-386.

Altmare, C., Norvell, W.A., Bjorkman, T., Harman, G.E. 1999. Solubilization of phosphates e micronutrients by the plant growth promoting e biocontrol fungus Trichoderma harzianum Rifai 1995-22. Appl. Environ. Microbiol. 65, 2926-2933.

Balemi, T., Negisho, K. 2012. Management of soil phosphorus and plant adaptation mechanisms to phosphorus stress for sustainable crop production: a review. J. Soil Sci. Plant Nutr. 12(3), 547-562.

Barroso, C.B., Nahas, E. 2008. Solubilization of hardly soluble iron phosphate in culture médium. Pesqui. Agropecu. Bras. 43(4), 529-535 (in Portuguese).

Embrapa. 1997. Manual for methods of soil analysis, 2nd ed. National Service for Soil Survey and Soil Conservation. Rio de Janeiro, Brazil, 212 p. (in Portuguese). 
Gravel, V., Antoun, H., Tweddell, R.J. 2007. Growth stimulation and fruit yield improvement of greenhouse tomato plants by inoculation with Pseudomonas putida or Trichoderma atroviride: possible role of indole acetic acid (IAA). Soil Biol. Biochem. 39(8), 1968-1977.

Hannan, M.A., Hasan, M.M., Hossain, I. 2013. Impact of dual inoculations with Rhizobium and Trichoderma on root rot disease and plant growth parameters of grasspea under field conditions. Persian Gulf Crop Prot. 2, 1-9.

Harman, G.E., Howell, C.R., Viterbo, A., Chet, I., Lorito, M. 2004. Trichoderma species opportunistic, avirulent plant symbionts. Nature Rev. Microbiol. 2(1), 43-56.

Holford, I.C.R. 1997. Soil phosphorus: its measurement, and its uptake by plants. Aust. J. Soil Res. 35, 227-239.

Ilmer, P., Schinner, F. 1992. Solubilization of inorganic phosphates by microorganisms isolated from forest soil. Soil Biol. Biochem. 24, 389-395.

Kapri, A., Tewari, L. 2010. Phosphate solubilization potential and phosphatase activity of rhizospheric Trichoderma spp. Braz. J. Microbiol. 41(3), 787795.

Machado, R.G., Sá, E.L.S., Damasceno, R.G., Hahn, L., Almeida, D., Moraes, T., Camargo, F.A.O., Reartes, D.S. 2011. Promotion of growth in plants Lotus corniculatus L. (birdsfoot trefoil) and Avena strigosa Schreb (black oat), by inoculation with rhizobia and Trichoderma harzianum. Sci. Nat. 33(2), 111-126 (in Portuguese).

Minaxi, Saxena, J., Chandra, S., Nain, L. 2013. Synergistic effect of phosphate solubilizing rhizobacteria and arbuscular mycorrhiza on growth and yield of wheat plants. J. Soil Sci. Plant Nutr. 13(2), 511-525.
Murphy, J., Riley, J.P. 1962. A modified single solution method for determination of phosphate in natural waters. Anal. Chem. Acta. 27, 31-36.

Nautiyal, C.S. 1999. An efficient microbiological growth medium for screening phosphorus solubilizing microorganisms. FEMS Microbiol. Lett. 170(1), 265-270.

Novais, R.F., Smyth, T.J. 1999. Phosphorus in soil and plant in tropical conditions. Federal University of Viçosa, Viçosa, MG, 399 p (in Portuguese).

Oliveira, A.G., Chagas, Jr A.F., Santos, G.R., Miller, L.O., Chagas, L.F.B. 2012. Potential phosphate solubilization and AIA production of Trichoderma spp. Green J. Agroecol. Sust. Develop. 7(3), 149155 (in Portuguese).

Reyes, I., Bernier, L., Antoun, H. 2002. Rock phosphate solubilization and colonization of maize rhizosphere by wild and genetically modified strain of Penicillium rugulosum. Microb. Ecol. 44, 39-48.

Rodrigues, L.A., Martins, M.A., Salomão, M.S.M.B. 2003. Use of mycorrhizas and rhizobium in intercropping system of eucalyptus and sesbania. II - Phosphorus uptake and efficiency of use and phosphate-fractions. Braz. J. Soil Sci. 27(4), 593599 (in Portuguese).

Rudresh, D.L., Shivaprakash, M.K., Prasad, R.D. 2005. Effect of combined application of Rhizobium, phosphate solubilizing bacterium and Trichoderma spp. on growth uptake and yield of chickpea (Cicer aritenium L.). Appl. Soil Ecol. 28, 139-146.

Santos, H.A., Mello, S.C.M., Peixoto, J.R. 2010. Association of isolates of Trichoderma spp. and indole-3-butyric acid (iba) in promoting root and growth of passion. Biosci. J. 26(6), 966-972 (in Portuguese). 
Schachtman, D.P., Reid, R.J., Ayling, S.M. 1998. Phosphate uptake by plants from soil to cell. Plant Physiol. 116, 447-453.

Schoebitz, M., Ceballos, C., Ciampi, L. 2013. Effect of immobilized phosphate solubilizing bacteria on wheat growth and phosphate uptake. J. Soil Sci. Plant Nutr. 13(1), 1-10.

Silva Filho, G.N., Narloch, C., Scharf, R. 2002. Solubilization of natural phosphates by microorganisms isolated from Pinus and Eucalyptus plantations in Santa Catarina, Brazil. Pesqui. Agropecu. Bras. 37(6), 847-854 (in Portuguese).

Silva, V.N., Guzzo, S.D., Lucon, C.M.M., Harakava, R. 2011. Growth promotion and resistance induction against anthracnose in cucumber using Trichoderma spp. Pesqui. Agropecu. Bras. 46(12), 1609-1618 (in Portuguese).

Souchie, E.L., Azcón, R., Barea, J.M., Saggin-Júnior, O.J., Silva, E.M.R. 2005. Phosphate solubilization in solid and liquid media by soil bacteria and fungi. Pesqui. Agropecu. Bras. 40(11), 1149-1152 (in Portuguese).
Subba Rao, N. S. 1999. Soil Microbiology (Fourth Edition of Soil Microorganisms and Plant Growth). Oxford \& IBH Publishing Co. Pvt. Ltd., New Delhi, 407 p.

Sujatha, S., Sirisham, S., Reddy, S.M. 2004. Phosphate solubilization by thermophilic microorganisms. Indian J. Microbiol. 44(2), 101-104.

Sutaliya, R., Singh, R.N. 2005. Effect of planting time, fertility level and phosphate solubilizing bacteria on growth, yield and yield attributes of winter maize (Zea mays) under rice (Oryza sativa) - maize cropping system. Indian J. Agron. 50, 173-175.

Vassilev, N., Medina, A., Azcón, R., Vassileva, M. 2006. Microbial solubilization of rock phosphate on media containing agro-industrial wastes and effect of the resulting products on plant growth and P uptake. Plant Soil. 287(1-2), 77-84.

Watts, R. J.; Chaudhary, D.K.; Tauro, P. 1988. Isolation and characterization of a new antifungal metabolite of Trichoderma reesei. Plant Soil. 107, $81-84$ 